\title{
Institutional Capacity of Forest Management Unit in Promoting Sustainable Community- Based Forest Management. Case Study of Forest Management Unit in Central Sulawesi Province, Indonesia
}

\author{
Sudirman Daeng Massiri ${ }^{1 *}$, Adam Malik ${ }^{1}$, Golar $^{1}$, Hamzari $^{1}$, Bramasto Nugroho ${ }^{2}$ \\ ${ }^{1}$ Faculty of Forestry, Tadulako University, Kampus Bumi Tadulako Tondo, Palu, Indonesia 94111 \\ ${ }^{2}$ Department of Forest Management, Faculty of Forestry and Environment, IPB University, Academic Ring Road, \\ Campus IPB Dramaga, Bogor, Indonesia 16680
}

Received March 26, 2020/Accepted July 14, 2020

\begin{abstract}
The main issue of forest management policies in Indonesia is strengthening the role of Forest Management Unit (FMU) and community-based forest management. This study describes the performance of FMU and the priority needs for the institutional strengthening of FMU to promote community-based forest management in Central Sulawesi Province. The research applied a case study's descriptive method by exploring, classifying, and understanding the meaning of the problems encountered by the object examined. The study shows that the performance of the FMUs was not yet optimal in promoting community-based forest management. This problem attributed to the weak institutional capacity of FMU. Several aspects of the institution need improvements, including strengthening its capacity at the resort level, fulfilling the needs and capacity building of extension staff, as well as providing a legal mechanism for financial management to facilitate its business activities and cooperation. These priority needs were affected by government bureaucratic issues. It necessary the policy formulation governing the strengthening of community-based forest management in the FMU area that supports the independence goals of FMU.
\end{abstract}

Keywords: strengthening local institution, social forestry, local institutional performance, forest management policy

*Correspondenceauthor,email:sudi_untad@yahoo.co.id

\section{Introduction}

Forest Management Unit, FMU (Kesatuan Pengelolaan Hutan, $K P H)$, plays a significant role in sustainable forest management practices (Kartodihardjo, 2014; Sahide et al., 2016). The Government of Indonesia commits to developing FMU in all forest areas, as mandated in Law Number 41 of 1999. FMU is a forest management organization at the site level (Maryudi, 2016). In Indonesia, FMU also has a responsibility to carry out public service functions related to forestry (Nugroho, 2014). FMU of Indonesia has the task of carrying out technical functions (arranging forest management plans and implementing its utilization of forest), managerial function (planning, monitoring and evaluation, and lays out national forestry policies), and business function (Hernowo \& Ekawati, 2014. The FMU should have a strong capacity to carry out its functions and responsibilities.

Forest management practices carried out by the FMU are not only to accomplish the ecosystem sustainability but also to accommodate the interests of the local community. The local communities living around forest areas have a high interest in forest resources. Most local communities depend their lives on forest and land resources in the forest area. On the one hand, the problem of forest areas managed by the state requires a high enforcement cost due to the wide management area. This situation reinforces the importance of community involvement in forest management (Djamhuri, 2008).

Community-based forest management is a concept of forest management to involve the community in forest governance (Gilmour, 2016), to result in the sustainability of forest resources (Porter-Bolland et al., 2012; Massiri et al., 2019), and reducing poverty of communities around the forest area (Mahanty et al., 2006). In Indonesia, this concept is embodied in social forestry policies through several forest management schemes. The local communities have legal access to forest management in the FMU area.

Community-based forest management requires robust local institutional capacity, as well as high institutional capacities of FMU. Institutional capacity is a description of the potential capacity and actor ability to realize collective goals (Dang et al., 2017). The collective goal of forest management is the sustainability of forest ecosystems and simultaneously improving the local communities' welfare. 
FMUs have the responsibility to ensure the sustainability of the functions of the forest area. They also have a role in empowering communities around forest areas through the facilitation of community access to forest resources and coaching to increase the capacity of communities around forest areas.

All forest areas in Central Sulawesi Province distributed into FMUs. Based on the Governor Regulation of Central Sulawesi Province Number 45 of 2016, there were 13 FMU organizations. The development of FMU in Central Sulawesi Province began in 2010. The first FMU to be built in 2010 was the FMU Dolago Tanggunung and FMU Dampelas Tinombo. Both these FMUs are FMU models in Central Sulawesi Province. FMU model is a role model that figures the ideal conditions of the development of FMU. These FMUs have operated for almost ten years, and they also have been getting a lot of precondition funding for operationalization in forest management. Supposedly, FMU Dampelas Tinombo and FMU Dolago Tanggunung should have a high capacity to perform sustainable forest management practices.

Previous research revealed that the institutional capacity of FMU's in Indonesia is still relatively weak due to the lack of resources (Setiajiati et al., 2017; Santoso et al. 2019). The institutional problems of FMU are related to the rule in use and government bureaucracy issues (Julijanti et al., 2014; Suwarno et al., 2014; Sahide et al., 2016). Referring to the institutional framework (Schmid, 2004), institutional performance determined by the situation and structure. The structure consists of rules and resources that shape actor behavior and actor power relations to realize a collective goal. This study examines the performance of FMU Dolago Tanggunung and FMU Dampelas Tinombo, as the FMU model in Central Sulawesi Province. In this article, we explain in the reason how the institutional structure and rules affect the capacity of FMU, and make suggestions the priority needs for strengthening the institutional capacity of the FMU to promote community-based forest management.

\section{Methods}

This research was conducted in two FMUs in Central Sulawesi Province that were FMU Dampelas Tinombo and FMU Dolago Tanggunung. These FMUs were the first FMU model established in Central Sulawesi Province and currently have funding facilitation to promote communitybased sustainable forest management. Based on the administration, the management area of the two FMUs located in the District of Sigi, Donggala, Poso, Parigi Moutong, and Palu.

The data were collected in 2018 , through the following stages; a) set the criteria for assessment, b) field observation, c) focus group discussion (FGD) at the local level with FMU officers to determine FMU performance and validate findings data in the field, d) in-depth interviews with the head of FMU Dolago Tanggunung and FMU Dampelas Tinombo, three staff from each the FMU, head of the Central Sulawesi provincial forestry service, two staff of the Central Sulawesi provincial forestry service, ten community leaders of social forestry, e) FGD at the provincial level to reveal the views of various stakeholders regarding the implementation of community-based sustainable forest management in the
FMU area and to validate the collected data.

This study applied the descriptive analysis of case studies, by exploring, classifying, and understanding the meaning of research object problems by carefully investigating a program, event, and process of the object of study. The units of analysis include a) institutional performance of FMU, b) structure and institutional capacity, c) policies and regulations that support the operationalization of FMUs, d) priority needs for institutional strengthening of FMUs to encourage the community-based forest management.

\section{Results and Discussion}

Performance of forest management unit The performance of FMUs focuses on: a) forest planning activitiy, b) community-based forest utilization, c) activities of forest and land rehabilitation, forest protection, and nature conservation.

Forest planning activity Forest management planning activity aims to ensure the sustainable use of forest resources (Akhadi et al., 2013). To carry out forest management, FMU should compile two planning documents, namely the longterm forest management plan and the short-term forest management plan. The document for long term forest management plan is a legal document that sets up a strategic plan for FMU at the site level for a 10-year time horizon and should be approved by the Ministry of Environment and Forestry (MoEF). This management plan elaborated on the short-term forest management plan and the business plan.

Forest management activity implemented by FMUs requires the appropriate planning. The appropriate planning depends on the availability of data, accurate problem analysis (Duvemo \& Lämås, 2006), and the proper planning process (Boukherroub et al., 2018). In this study, the indicators for assessing the activity of forest planning include a) the availability of forest resource inventory data, b) forest planning process, c) legality of planning documents, d) internalization, and e) implementation (Table 1).

The content of the long-term forest management planning document of FMU was comprehensive so that it requires the completed data and expertise in the planning process. This document consists of: 1) background, 2) description of forest area, 3) vision and mission of forest management, 4) analysis and projection, 5) strategic action plan, 6) coaching, supervision, and control, 7) monitoring, evaluation, and reporting (Hernowo \& Ekawati, 2014). The arranged strategic action plan of FMU considers several aspects, including the potential conditions and problems of the forest area, strategic issues, and vision and mission to be accomplished. The strategic action plan of FMU includes; a) periodic forest inventory and forest area arrangement, b) forest utilization in certain forest area, c) community empowerment, d) guidance and monitoring of forest resources utilization and forest area utilization, e) forest rehabilitation outside the licensed area, f) coaching and monitoring rehabilitation and reclamation in licensed areas, g) implementation plan for forest protection and nature conservation, h) implementation plan for coordination and synchronization between the license holder, i) coordination and synergy of the program with related institutions and 
Table 1 Forest panning activities of FMUs

\begin{tabular}{|c|c|c|c|}
\hline \multirow[b]{2}{*}{ Indicators } & \multicolumn{2}{|c|}{ Category } & \multirow[b]{2}{*}{ Finding and verifier } \\
\hline & $\begin{array}{c}\text { FMU } \\
\text { Dampelas } \\
\text { Tinombo }\end{array}$ & $\begin{array}{c}\text { FMU } \\
\text { Dolago } \\
\text { Tanggunung }\end{array}$ & \\
\hline $\begin{array}{l}\text { The availability } \\
\text { of forest } \\
\text { resource } \\
\text { inventory data }\end{array}$ & $\begin{array}{l}\text { Moderate } \\
(2)\end{array}$ & $\begin{array}{l}\text { Moderate } \\
\text { (2) }\end{array}$ & $\begin{array}{l}\text { Inventory data of forest resource potential has not yet available } \\
\text { completely and comprehensively to support forest plan }\end{array}$ \\
\hline $\begin{array}{l}\text { Forest planning } \\
\text { process }\end{array}$ & $\begin{array}{l}\text { Moderate } \\
\text { (2) }\end{array}$ & $\begin{array}{l}\text { Moderate } \\
\quad(2)\end{array}$ & $\begin{array}{l}\text { The process of preparing a document of planning was not compiled } \\
\text { by the FMU manager itself, but arranged by the expert and involves } \\
\text { the team formed by the Forest Area Consolidation Center (BPKH } \\
\text { Wilayah XVI Palu). Not all staff of FMU was involved in the } \\
\text { planning process. }\end{array}$ \\
\hline $\begin{array}{l}\text { The legality of } \\
\text { planning } \\
\text { documents }\end{array}$ & $\begin{array}{c}\text { Good } \\
(3)\end{array}$ & $\begin{array}{l}\text { Moderate } \\
\quad(2)\end{array}$ & $\begin{array}{l}\text { FMU Dampelas Tinombo: All management units have the } \\
\text { document forest plan. The FMU manager has revised the document } \\
\text { based on the social-economic dynamics and condition of forest } \\
\text { resources. However, the revised forest planning document has not } \\
\text { been approved by MoEF because of no rules regulating the legality of } \\
\text { the revised forest plan document. FMU Dolago Tanggunung: Most } \\
\text { of the planning documents got approved by the MoEF. However, the } \\
\text { planning document for management unit IX was still revised divided } \\
\text { into two management units, namely management unit VI and IX. }\end{array}$ \\
\hline Internalization & $\begin{array}{l}\text { Moderate } \\
\quad(2)\end{array}$ & $\begin{array}{l}\text { Moderate } \\
\quad(2)\end{array}$ & $\begin{array}{l}\text { The public consultation conducted at the district level and its } \\
\text { recommendations used to improve the planning; The planning } \\
\text { document has not internalized in the regional midterm management } \\
\text { plan of the Central Sulawesi Province.; The long-term forest } \\
\text { management plan of FMU referred to the regional spatial plan and } \\
\text { provincial development. }\end{array}$ \\
\hline Implementation & $\begin{array}{c}\text { Low } \\
(1)\end{array}$ & $\begin{array}{c}\text { Low } \\
(1)\end{array}$ & $\begin{array}{l}\text { The short-term forest management plan referred to the long-term } \\
\text { forest management plan. However, the planning could not be } \\
\text { implemented entirely; The financing funds from the state government } \\
\text { budget, and local government budget, as well as donors, were not } \\
\text { sufficient to finance the implementation of all the forest planning; } \\
\text { The implemented programs were adjusted based on the priority } \\
\text { problems of FMU. }\end{array}$ \\
\hline $\begin{array}{l}\text { Overall } \\
\text { Indicator }\end{array}$ & $\begin{array}{c}\text { Moderate } \\
(\mathbf{1 0})\end{array}$ & $\begin{array}{c}\text { Moderate } \\
(9)\end{array}$ & \\
\hline
\end{tabular}

stakeholders, j) provision and improvement of human resources capacity, k) providing funding, 1) rationalization plan for the management area, $\mathrm{m}$ ) review of the management plan, and n) development of the investment.

The process of preparing the long-term forest planning document was applying the type of participatory planning. The planning document was compiled by experts, followed by public consultations to obtain input and refinement (Rustiadi, 2018). The long-term forest planning document of the FMUs compiled by the expert. Data used in the plan preparation was provided by the Forest Area Consolidation Center (BPKH Wilayah XVI Palu) through forest inventory activities. The draft of the long-term forest planning document then discussed with relevant parties, including the FMU management, Central Sulawesi Provincial Forestry Service, BPKH Wilayah XVI Palu, Watershed and Protection Forest Management Center (BPDAS HL Palu Poso), and Production Forest Management Center (BPHP Wilayah XII $P a l u)$ to obtain input and improvements. It followed with public consultation at the district level.

The document of the plan could not be implemented entirely due to insufficient data in the planning process. The insufficiency was the socioeconomic aspect, especially community access to forest resources. Some forest areas accessed by the community but not designated as blocks for community empowerment. Also, the long-term forest management plan has not supported by the completed data on the potential and distribution of non-timber forest products. The obstacles in collecting data on potential forest resources include technology and human resource capacity (Bettinger et al., 2016). In this case, this problem also affected by the weak funding capacity of FMU. The collected data on the potential of forest resources is comprehensively and periodically so that it requires high costs. This situation confirms that the problem of forest management managed by the state is high information costs (De Royer et al., 2018).

The performance forest planning activities of FMUs in Central Sulawesi province was moderate. Forest planning documents were compiled and obtained legally from the MoEF. However, the implementation of the plan was still in the low category. The long-term forest management planning document, with a 10-year time horizon, could not be entirely implemented in an annual activity plan, apart from insufficient data, the obstacles in the plan implementation related to the issue of legality, and the funding capacity of FMU.

According to FMUs managers, the forest planning document approved by MoEF should be revised, by integrating it with the dynamics of socioeconomic conditions, the up to date data on forest resource potential, 
and new regulation. The two FMUs of Central Sulawesi Province have reviewed their forest management planning. However, the reviewed management plan document could not be implemented as a legal document because it has not yet approved by MoEF. At the moment, there has been no legal mechanism that regulates the attestation of the document review of the long-term forest management plan. Administrative and legal issues often perceived as an obstacle in implementing forest management (McCarthy, 2004; Suwarno et al., 2014; Supratman et al., 2019). Sustainable forest management in Indonesia is more of administrative liability obligation fulfillment rather than performance-based fulfillments (Yovi \& Nurrochmat, 2018).

FMU could not implement the strategic action plan entirely because of adequate funding. The source of funding to finance forest management was the state government budget (Anggaran Pendapatan dan Belanja Negara, APBN), local government budget (Anggaran Pendapatan dan Belanja Daerah, $A P B D$ ), and donor funds. The availability of these funds is mostly allocated for preconditioning activities in realizing forest management, not for management activities, as set out in the planning document.

In the framework of strengthening FMU funding, three funding models that can be applied; 1) fully funded by the state (state government-centric), 2) based on market mechanisms that rely on government investment (market government), and 3) integrating the two models through participatory government, flexible government, and strengthening social networks. Based on the three models, the third model is more appropriate to be implemented, namely through the financial management pattern of the local public service agency (Badan Layanan Umum Daerah, BLUD) (Nugroho, 2014).
The activities of community-based forest resource utilization business The planned forest resource utilization in the FMU area includes the timber product utilization from natural forest and plantation forest, the business of natural tourism, and the business of non-timber forest product utilization. This study revealed that activities of communitybased forest resource utilization business were still low category (Table 2). The running business activity was the only business of non-timber forest product utilization. However, it was still in the initial stage, providing infrastructure and training for capacity building for farmer groups.

The non-timber forest product utilization business in the FMU area was developed in collaboration with the community group. The business utilizing NTFPs developed by FMU Dampelas Tinombo was sugar production and rubber plantations. In the Dolago Tanggunung FMU area, the activities for utilizing NTFPs included honey bee cultivation and rattan and patchouli processing. This business was already running on the production stage, but faces obstacles in business development, specifically related to the legality of the business carried out by FMU, as a government organization. This is stipulated in the MoEF regulation Number P.49/MENLHK/SET/KUM.1/9/2017, which stated that the FMU conducting forest utilization cooperation should apply the financial management pattern of $B L U D$ or other financial patterns subsequently regulated in government.

The activities of forest and land rehabilitation, forest protection and nature resources conservation The activities planned for the sustainability of forest functions in the FMU area were forest and land rehabilitation, forest protection, and

Table 2 Performance of forest utilization business

\begin{tabular}{|c|c|c|c|c|}
\hline & \multirow[b]{2}{*}{ Indicators } & \multicolumn{2}{|c|}{ Category } & \multirow[b]{2}{*}{ Finding and verifier } \\
\hline & & $\begin{array}{l}\text { FMU } \\
\text { Dampelas } \\
\text { Tinombo }\end{array}$ & $\begin{array}{c}\text { FMU } \\
\text { Dolago } \\
\text { Tanggunung }\end{array}$ & \\
\hline 1 & $\begin{array}{l}\text { The business of } \\
\text { Timber product } \\
\text { utilization from the } \\
\text { natural forest }\end{array}$ & $\begin{array}{l}\text { Low } \\
(1)\end{array}$ & $\begin{array}{l}\text { Low } \\
(1)\end{array}$ & $\begin{array}{l}\text { There has been no timber forest product utilization activity, } \\
\text { even though it has planned because it has not supported by } \\
\text { regulation and funding }\end{array}$ \\
\hline 2 & $\begin{array}{l}\text { The business of } \\
\text { Timber product } \\
\text { utilization from the } \\
\text { planted forest }\end{array}$ & $\begin{array}{l}\text { Low } \\
(1)\end{array}$ & $\begin{array}{l}\text { Low } \\
(1)\end{array}$ & $\begin{array}{l}\text { The planning of plantation forest development has not been } \\
\text { implemented. }\end{array}$ \\
\hline 3 & $\begin{array}{l}\text { The business of } \\
\text { natural tourism }\end{array}$ & $\begin{array}{l}\text { Low } \\
(1)\end{array}$ & $\begin{array}{l}\text { Low } \\
(1)\end{array}$ & It has not been developed \\
\hline 4 & $\begin{array}{l}\text { The business of non- } \\
\text { timber forest product } \\
\text { utilization }\end{array}$ & $\begin{array}{l}\text { Moderate } \\
\text { (2) }\end{array}$ & $\begin{array}{l}\text { Moderate } \\
\quad(2)\end{array}$ & $\begin{array}{l}\text { There has been an initial initiation of business development in } \\
\text { the form of equipment assistance, product testing, but } \\
\text { production and marketing activities have not yet run. } \\
\text { the non-timber forest product business initiations that have } \\
\text { been developed by FMU Dampelas Tinombo includes the } \\
\text { business of palm sugar, dan rubber plantation; } \\
\text { The non-timber forest product business initiations that have } \\
\text { been developed by FMU Dolago Tanggunung includes the } \\
\text { business of forest honey, rattan, patchouli processing. }\end{array}$ \\
\hline & Overall Indicator & $\begin{array}{l}\text { Low } \\
(5)\end{array}$ & $\begin{array}{l}\text { Low } \\
(5)\end{array}$ & \\
\hline
\end{tabular}


natural resources conservation. This research reveals that the performance of the FMU in carrying out these activities was still in the low category (Table 3 ).

Forest and land rehabilitation activities of FMU were only planted outside the forest areas, using the local government budgets. The allocation of the local government budgets, based on formal rules, could not be spent on a program in the forest area. The funding sources for a rehabilitation program in forest areas use the state government budgets, through the director-general of watershed and protection forest management (Dirjen PDAS $H L)$. However, the use of state government budget for rehabilitation programs is only intended for rehabilitation in the protected forest area, not in the production forest, even though there are many critical areas in the production forest area.

This study shows that the performance of forest protection activities carried out by the two FMUs was a moderate category. Forest protection activity conducted by FMU was only a periodic patrol. Due to the lack of staff members and the wide management area, the illegal activities in the forest management area could not adequately be monitored and controlled. This problem situation may cause open access to the forest area and lead to forest degradation and deforestation. The strategy for overcoming this problem situation is through strengthening the social network. The social network is a component of social capital (Putnam, 1993). Research conducted (Nepal et al., 2007) revealed that strengthening social networks in conservation programs is positively correlated with the number of plants grown on private land. It also has a positive impact on the Sloping Land Conservation Program (Lan \& Liu, 2019). Strengthening social networks through effective communication and collaboration patterns can also reduce transaction costs (Uphoff, 2000).

Problem situation of forest management unit Low institutional capacity of forest management unit The capacity of the institution determines its performance. In this study, six components of the institutional capacities of FMU evaluated. These components are critical in strengthening FMU in Indonesia (Wulandari \& Setyaso, 2014). This research showed that the two FMU in central Sulawesi were in low category (Table 4).

The problem of weak FMUs institutional capacity in Central Sulawesi was attributed to the number of staff that was not spread evenly at the site level. The number of FMU's staff at the resort level was inadequate, especially extension workers and community empowerment facilitators. Implementation of community-based forest management requires extension workers and facilitators of community empowerment.

High enforcement cost for forest area Ownership of natural resources in the forest areas of FMU is a state property. High enforcement cost is the main threat to resources owned by the state. In case this threat is not resolved, the forest would become open access, leading to resource damage (Ostrom, 2005).

FMU Dolago Tanggunung has three management units, namely Unit VI, Unit IX, and Unit V. The total area of all the three management units is \pm 273.816 ha, which was managed by 55 personnel. Meanwhile, FMU Dampelas Tinombo has two management units, namely unit III and unit IV. The total management area of FMU Dampelas Tinombo is $\pm 247,005$ ha, which was managed by 30 personnel. The wide management area and the limited number of management personnel lead to high enforcement costs of forest resources (Banana \& Gombya-Ssembajjwe, 2000; Fraser, 2019).

The stability of forest area recognized by all parties is one of the main requirements for realizing forest resource sustainability. The strategy policy implemented to promote the forest area stability in the FMU is through the demarcation. The forest boundaries demarcation is the responsibility of the Forest Area Consolidation Center (BPKH Wilayah XVI Palu). In contrast, the forest management block demarcation is under FMU. The forest management area of FMU Dampelas Tinombo has been carried out an external boundary arrangement by $75 \%$, while the forest area management of FMU Dolago Tanggunung ranged from $5075 \%$.

The results study conducted by Golar (2019) revealed that there were still tenure conflicts in the forest area of the FMU area, especially in the utilization of forest resources. The policy strategy implemented by FMU to overcome this problem situation was through the social forestry program.

Table 3 Performance of forest and land rehabilitation, forest protection and natural resources conservation activities

\begin{tabular}{|c|c|c|c|c|}
\hline & \multirow[b]{2}{*}{ Indicators } & \multicolumn{2}{|c|}{ Category } & \multirow[b]{2}{*}{ Finding and verifier } \\
\hline & & $\begin{array}{l}\text { FMU } \\
\text { Dampelas } \\
\text { Tinombo }\end{array}$ & $\begin{array}{c}\text { FMU } \\
\text { Dolago } \\
\text { Tanggunung }\end{array}$ & \\
\hline 1 & $\begin{array}{l}\text { Forest and land } \\
\text { rehabilitation activities }\end{array}$ & $\begin{array}{l}\text { Moderate } \\
\text { (2) }\end{array}$ & Moderate & $\begin{array}{l}\text { Forest and land rehabilitation has not implemented according } \\
\text { to the planning. Forest and land rehabilitation activities were } \\
\text { conducted outside the forest area using the provincial } \\
\text { government budgets. }\end{array}$ \\
\hline 2 & $\begin{array}{l}\text { Forest protection } \\
\text { activities }\end{array}$ & $\begin{array}{l}\text { Moderate } \\
\text { (2) }\end{array}$ & $\begin{array}{l}\text { Moderate } \\
\text { (2) }\end{array}$ & $\begin{array}{l}\text { Forest protection activities conducted every year, but it not yet } \\
\text { optimal because of the vast management area while the } \\
\text { availability of resources was insufficient. }\end{array}$ \\
\hline \multirow[t]{2}{*}{3} & $\begin{array}{l}\text { Natural resources } \\
\text { conservation activities }\end{array}$ & $\begin{array}{l}\text { Low } \\
(1)\end{array}$ & $\begin{array}{l}\text { Low } \\
(1)\end{array}$ & $\begin{array}{l}\text { There has been no activities and has not to be supported by } \\
\text { budget planning and allocation. }\end{array}$ \\
\hline & Overall Indicator & $\begin{array}{c}\text { Low } \\
\text { (5) }\end{array}$ & $\begin{array}{l}\text { Low } \\
\text { (5) }\end{array}$ & \\
\hline
\end{tabular}


Table 4 Institutional capacity of FMUs in Central Sulawesi

\begin{tabular}{|c|c|c|c|c|}
\hline & \multirow[b]{2}{*}{ Indicators } & \multicolumn{2}{|c|}{ Category } & \multirow[b]{2}{*}{ Finding and verifier } \\
\hline & & $\begin{array}{c}\text { FMU } \\
\text { Dampelas } \\
\text { Tinombo }\end{array}$ & $\begin{array}{c}\text { FMU } \\
\text { Dolago } \\
\text { Tanggunung }\end{array}$ & \\
\hline 1 & $\begin{array}{l}\text { Distribution of } \\
\text { management staffs } \\
\text { based on the territory } \\
\text { of the management } \\
\text { unit }\end{array}$ & $\begin{array}{l}\text { Low } \\
(1)\end{array}$ & $\begin{array}{l}\text { Low } \\
(1)\end{array}$ & Staffs are not evenly distributed and insufficient \\
\hline 2 & $\begin{array}{l}\text { Adequacy of staff } \\
\text { based on workload }\end{array}$ & $\begin{array}{l}\text { Low } \\
(1)\end{array}$ & $\begin{array}{l}\text { Low } \\
(1)\end{array}$ & $\begin{array}{l}\text { The workload was considered quite large, while the staff is very } \\
\text { limited } \\
\text { The number of staff at the FMU office was sufficient, but at the } \\
\text { number of staff at the resort was still lacking }\end{array}$ \\
\hline 3 & $\begin{array}{l}\text { legal readiness to } \\
\text { conduct business } \\
\text { activities }\end{array}$ & $\begin{array}{l}\text { Moderate } \\
\quad(2)\end{array}$ & $\begin{array}{l}\text { Moderate } \\
\text { (2) }\end{array}$ & $\begin{array}{l}\text { Still in the process of preparing documents requirements for the } \\
\text { implementation of the Financial Management Pattern of } B L U D\end{array}$ \\
\hline 4 & $\begin{array}{l}\text { Facility and } \\
\text { infrastructure }\end{array}$ & $\begin{array}{l}\text { Low } \\
(1)\end{array}$ & $\begin{array}{l}\text { Low } \\
(1)\end{array}$ & Facility and infrastructure at Resort level was still lacking \\
\hline 5 & $\begin{array}{l}\text { The availability of } \\
\text { staff for Forestry } \\
\text { extension and } \\
\text { community } \\
\text { empowerment }\end{array}$ & $\begin{array}{l}\text { Low } \\
(1)\end{array}$ & $\begin{array}{l}\text { Low } \\
(1)\end{array}$ & $\begin{array}{l}\text { FMU Dampelas Tinombo: } \\
\text { There was not available the forestry extension and community } \\
\text { empowerment staffs } \\
\text { FMU Dolago Tanggunung: } \\
\text { There was only } 1 \text { forestry extension staff }\end{array}$ \\
\hline 6 & Financing capacity & $\begin{array}{l}\text { Moderate } \\
\quad(2)\end{array}$ & $\begin{array}{l}\text { Moderate } \\
\text { (2) }\end{array}$ & $\begin{array}{l}\text { The budget was available, but not sufficient to support forest } \\
\text { management as planned. } \\
\text { Budgeting was not based on planning as outlined in the long- } \\
\text { term forest management plan (RPHJP) }\end{array}$ \\
\hline & Overall Indicator & $\begin{array}{c}\text { Low } \\
(8)\end{array}$ & $\begin{array}{c}\text { Low } \\
(8)\end{array}$ & \\
\hline
\end{tabular}

Progress on SF schemes in the FMU area was described in (Table 5)

Research conducted by Malik (2019), shows that the institutional capacity of community forestry (Hutan Kemasyarakatan, $\mathrm{HKm}$ ) groups and village forest managers in Central Sulawesi Province was weak. Most of the community forestry groups with approved management have not implemented management activity. A number of them did not even have a management plan document. Several $\mathrm{HKm}$ groups and village forest managers were assisted by NGOs, though it was not sustainable. After the mentoring ended, several HKm groups had not implemented the programs planned. This confirms the importance of continuous assistance to the group.

The results of the FGDs carried out by the Central Sulawesi Social Forestry Acceleration Working Group recommended that the FMU should improve services, specifically group assistance in its working area. The roles of the FMU related to social forestry program, as set out in the formal rules, include a) facilitate and precondition social forestry licensing, b) approve the management plan and annual work plan, and c) carry out monitoring and evaluation of social forestry licenses.

Priority needs for strengthening the institutional capacity of FMU in empowering community-based sustainable forest management The FMU plays a critical role in supporting community-based forest management through social forestry programs. However, FMU's institutional capacity was currently not optimal and needs capacity strengthening.
Strengthening the institutional capacity of FMU at resort level Implementation of community-based forest management requires the critical role of FMU on the resort level to provide services to community groups. The low institutional capacity, in many cases, is an obstacle to collaborative forest management (Massiri et al., 2015). The institutional capacity of the two FMUs studied was relatively in the low category, particularly at the resort level. Institutional capacity of FMU at the resort level was the inadequate distribution of personnel, including forest police personnel, extension workers, and empowerment facilitators.

The policy strategy for recruiting FMUs personnel faces obstacles related to budgeting, both from the MoEF and the local government. Foresters' volunteers should be included in management activities at the resort level. They should be authorized to strengthen the extension and empowerment activity at the resort level. This policy should be supported by strengthening and improving the forest volunteers' knowledge and skills on community empowerment, conflict resolution, and entrepreneurship training.

Strengthening the capacity of FMU institutions depends on the government bureaucracy issue (Sahide et al., 2016; Tajuddin et al., 2019). The vagueness authority and responsibility between the MoEF and the provincial government for institutional strengthening at the site level in terms of supporting SF programs is an obstacle to community-based forest management. Funding for the SF program comes from the Social Forestry Center and Environmental Partnership (Balai Perhutanan Sosial dan Kemitraan Lingkungan, BPSKL). In contrast, the 
sustainability of the SF program depends on the role of the FMU at the resort level. However, FMUs have a weak institutional capacity and did not have a sufficient budget to support the SF program. This situation negatively affected the community-based forest management programs.

As an organization that carries out bureaucratic functions, FMU has two main goals, that are providing public services and the pursuit of interest organizations as independent organizations. The development of communitybased forest management through the SF scheme depends on the FMU bureaucracy's role at the site level. Communitybased forest management programs in the FMU area should consider obtaining income that supports its independence goals. Therefore, it is necessary to review and formulate policies governing the mechanism and synchronization of the FMU system and the SF scheme on community-based forest management.

Empowering the institutional capacity of social forestry Community-based forest management schemes developed in the FMU area, specifically at the research location, were social forestry schemes, consist of village forests, community forestry, a community forest plantation, and partnerships. The provision of access to forest resources should be supported by capacity building so that the community can manage, control, and utilize forest resources (Ostrom, 2005). In this community-based forest management scheme, FMU managers should have a dominant role in facilitating preconditions and strengthening the role of social forestry farmer' groups (Setiajiati et al., 2017).

The important roles of FMU that should be optimized in supporting social forestry policies are a) facilitating preparation and formation of farmer groups and SF licensing (HKm, HD, HTR, HA, and partnership), b) facilitation and mentoring to farmer groups in preparing participatory plans for SF group activities, c) facilitation and mentoring to SF farmer groups in business development, and d) mentoring to strengthen SF's institutional capacity.

Establishing a legal mechanism for business activities and partnership of forest resources utilization The legal basis qualification becomes the barrier of FMU to develop the business of forest resources, related to the profit-sharing mechanism and revenue from the forest utilization business carried out. FMU is a quasi-governmental organization, which it be allowed to carry out business activities in forest management, as long as applying the financial management pattern of $B L U D$ or other financial management patterns that support business activities approved by the government (Nugroho, 2014).

Some donor agencies have facilitated the preconditioning program to address the business legality of the two FMUs, included: a) facilitating for strengthening knowledge and skills regarding the preparation requirements for the financial management pattern of BLUD for FMU Dolago Tanggunung sponsored by FAO, b) facilitating the provision of requirements for the financial management pattern of BLUD for FMU Dampelas Tinombo sponsored by Word Bank, and c) facilitating for the preparation of regional regulations on forest management in the FMU area, sponsored by Forclime.

Both FMUs were currently still preparing administrative requirements for proposing a financial management pattern of BLUD. Instead, the Central Sulawesi Provincial Government issued a regional regulation on the mechanism of retribution on the use of forest resources in the FMU area to support business activities for the FMU. Nevertheless, this retribution mechanism cannot support the flexibility of the FMU in developing the business of utilizing forest resources compared to the $B L U D$ financial management pattern mechanism.

\section{Conclusion}

The institutional capacity of FMU, particularly at the resort level, has a critical role in facilitating the implementation of community-based forest management. The performance of community-based forest management in the FMUs area of Central Sulawesi Province was still relatively low. The weak institutional capacity of FMUs at the resort level and the high forest enforcement cost were the problem situations confronted by managers. The strategy that could be carried out in strengthening the institutional capacity of FMU at the resort level is to optimize the role of foresters' volunteers and strengthen the social network of FMU at the site level. The priority needs for strengthening FMU in promoting community-based forest management are closely related to the government bureaucratic issue concerning with the FMU system and the SF program. It is necessary to review and formulate policies governing the mechanism and synchronization of FMU system and SF program, related community-based forest management.

Table 5 Progress on SF schemes in FMU area

\begin{tabular}{lcccc}
\hline & \multicolumn{2}{c}{ FMU Dampelas Tinombo } & FMU Dolago Tanggunung \\
\cline { 2 - 5 } Social forestry schemes & $\begin{array}{c}\text { Number of } \\
\text { permits }\end{array}$ & Area (ha) & Number of permit & Area (ha) \\
\hline SF Approval & & & & 218,00 \\
Village forest $(H D)$ & 1 & $1.840,00$ & 1 & $7.891,00$ \\
Community forestry $(H K m)$ & 1 & & 2 & 950,00 \\
SF in the Approval Process & & $16.544,00$ & 17 & $13.794,24$ \\
Village forest $(H D)$ & 10 & $1.126,00$ & 0 & 0,00 \\
Community forestry $(H K m)$ & 6 & $5.410,00$ & 0 & 0,00 \\
Community forest plantation $(H T R)$ & 1 & 120,00 & & 0 \\
Partnership (Kemitraan) & 2 & & & \\
\hline
\end{tabular}


Community-based forest management programs in the FMU area should consider how FMU can obtain income that supports its independence goals.

\section{References}

Akhadi, K., Wijaya, A. F., \& Hardjanto, I. (2013). Perencanaan pembangunan kehutanan daerah dalam perspektif good governance. Jurnal Penelitian Kehutanan Wallacea, 2, 51-64. https:// doi.org/10.18 330/jwallacea.2013.vol2iss1pp51-64

Banana, A. Y., \& Gombya-Ssembajjwe, W. (2000). Successful forest management: Ine importance of security of tenure and rule enforcement in Ugandan forests. People and forests: Communities, Institutions, and Governance, 87.

Bettinger, P., Boston, K., Siry, J. P., \& Grebner, D. L. (2016). Forest management and planning. Academic Press.

Boukherroub, T., D'amours, S., \& Rönnqvist, M. (2018). Sustainable forest management using decision theaters: Rethinking participatory planning. Journal of Cleaner Production, 179, 567-580. https://doi.org/10.1016/ j.jclepro.2018.01.084

de Royer, S., van Noordwijk, M., \& Roshetko, J. (2018). Does community-based forest management in Indonesia devolve social justice or social costs? International Forestry Review, 20, 167-180. https://doi.org/10.1505/ 146554818823767609

Djamhuri, T. L. (2008). Community participation in a social forestry program in Central Java, Indonesia: the effect of incentive structure and social capital. Agroforestry Systems, 74, 83-96. https://doi.org/10.1007/s10457-0089150-5

Duvemo, K., \& Lämås, T. (2006). The influence of forest data quality on planning processes in forestry. Scandinavian Journal of Forest Research, 21, 327-339. https://doi.org/10.1080/02827580600761645

Dang, T. K. P., Visseren Hamakers, I. J., \& Arts, B. (2017). The institutional capacity for forest devolution: The case of forest land allocation in Vietnam. Development Policy Review, 35, 723-744. https://doi.org/10.1111/dpr.12251

Fraser, A. (2019). Costs of forest management and regeneration. In Achieving the sustainable management offorests. (pp143158). New York: Springer.

Gilmour, D. (2016). Forty years of community-based forestry: A review of its extent and effectiveness. Food Agriculture Organization of United Nations.

Golar (2019). Potensi konflik tenurial di Wilayah KPH Dampleas Tinombo. Palu: Fakultas Kehutanan Universitas Tadulako

Hernowo, B., \& Ekawati, S. (2014). Operasionalisasi kesatuan pengelolaan hutan (KPH): Langkah awal menuju kemandirian. Yogyakarta: Kanisius,.
Julijanti, J., Nugroho, B., Kartodihardjo, H., \& Nurrochmat, D. R. (2014). Policy adoption of forest management unit: A knowledge diffusion analysis. Jurnal Manajemen Hutan Tropika, 20(2), 94-102. https://doi.org/10.7226/ jtfm.20.2.94

Lan, J., \& Liu, Z. (2019). Social network effect on income structure of SLCP participants: Evidence from Baitoutan Village, China. Forest Policy and Economics, 106, 101958. https://doi.org/10.1016/j.forpol.2019.101958

Kartodihardjo, H. (2014). Urgensi transformasi struktur kehutanan Indonesia. In Sugiharto, Strategi pengembangan KPH dan perubahan struktur kehutanan Indonesia. Jakarta: Direktorat Jenderal Planologi Kehutanan Kementerian Lingkungan Hidup dan Kehutanan.

Kusumedi, P., \& Rizal, A. (2010). Analisis stakeholder dan kebijakan pembangunan KPH Model Maros di Propinsi Sulawesi Selatan. Jurnal Analisis Kebijakan Kehutanan, 7, 179-193.

Mahanty, S., Gronow, J., Nurse, M., \& Malla, Y. (2006). Reducing poverty through community-based forest management in Asia. Journal of Forest and Livelihood, 5 , 78-89. https://doi.org/10.3126/jfl.v5i1.1983

Malik, A. (2019). Kajian dampak perhutanan sosial Provinsi Sulawesi Tengah. Palu: Fakultas Kehutanan Universitas Tadulako Kerjasama Balai Perhutanan Sosial dan Kemitraan Lingkungan Wilayah Sulawesi,.

Maryudi, A. (2016). Arahan tata hubungan kelembagaan kesatuan pengelolaan hutan (KPH) di Indonesia. Jurnal Ilmu Kehutanan, 10, 57-64. https://repository.ugm.ac.id/ $\mathrm{id} /$ eprint/274394

Massiri, S. D., Nugroho, B., Kartodihardjo, H., \& Soekmadi, R. (2015). Institutional sustainability barriers of community conservation agreement as a collaboration management in Lore Lindu National Park. Jurnal Manajemen Hutan Tropika, 21, 147-154. https://doi.org/ 10.7226/jtfm.21.3.147

Massiri, S. D., Nugroho, B., Kartodihardjo, H., \& Soekmadi, R. (2019). Institutional sustainability of a community conservation agreement in Lore Lindu National Park. Forest and Society, 3(1), 64-76. https://doi.org/10. 24259/fs.v3i1.5204

McCarthy, J. F. (2004). Changing to gray: Decentralization and the emergence of volatile socio-legal configurations in Central Kalimantan, Indonesia. World Development, 32, 1199-1223. https://doi.org/10.1016/j.worlddev. 2004.02.002

Nepal, M., Bohara, A. K., \& Berrens, R. P. (2007). The impacts of social networks and household forest conservation efforts in rural Nepal. Land Economics, 83, 174-191. https://doi.org/10.3368/le.83.2.174

Nugroho, B. (2014). Menuju KPH mandiri, apa yang harus dilakukan? In Sugiharto, Strategi pengembangan KPH 
dan perubahan struktur kehutanan di Indonesia. Jakarta: Direktorat Jenderal Planologi Kehutanan Kementerian Lingkungan Hidup dan Kehutanan.

Ostrom, E. (2005). Self-governance and forest resources. In P. J. Shah \& M. Vidisha, Terracotta reader. A market approach to environment. New Delhi: Academic Foundation in association with Centre for Civil Society.

Porter-Bolland, L., Ellis, E. A., Guariguata, M. R., RuizMallén, I., Negrete-Yankelevich, S., \& Reyes-García, V. (2012). Community managed forests and forest protected areas: An assessment of their conservation effectiveness across the tropics. Forest Ecology and Management, 268, 6-17.https://doi.org/10.1016/j.foreco.2011.05.034

Putnam, R. D. (1993). The prosperous community: Social capital and public life. The American Prospect, 4(13), $35-42$.

Ruhimat, I. S. (2010). Implementasi kebijakan Kesatuan Pengelolaan Hutan (KPH) di Kabupaten Banjar. Jurnal Penelitian Sosial dan Ekonomi Kehutanan, 7, 29094.

Rustiadi, E. (2018). Perencanaan dan pengembangan wilayah. Indonesia:Yayasan Pustaka Obor.

Sahide, M. A. K., Supratman, S., Maryudi, A., Kim, Y.-S., \& Giessen, L. (2016). Decentralization policy as a recentralisation strategy: Forest management units and community forestry in Indonesia. International Forestry Review, 18, 78-95. https://doi.org/10.1505/14655481 6818206168

Santoso, S. S., Nurrochmat, D. R., Nugroho, B., \& Santoso, I. (2019). The feasibility of the implementation of forest management units' (FMUs') policy: A case study in FMU Yogyakarta and FMU Region IX Panyabungan. Jurnal Manajemen Hutan Tropika, 25, 1-16. https://doi.org/10. 7226/jtfm.25.1.1

Schmid, A. A. (2004). Conflict and cooperation; institutional and behavioral economics. London:
Blackwell Publishing.

Setiajiati, F., Hardjanto, H., \& Hendrayanto, H. (2017). Strategies of community empowerment to manage protection forest sustainably. Jurnal Manajemen Hutan Tropika, 23, 71-80. https://doi.org/10.7226/jtfm.23.2.71

Suwarno, E., Kartodihardjo, H., Kolopaking, L. M., \& Soedomo, S. (2014). Institutional obstacles on the development of forest management unit: The case of Indonesian Tasik Besar Serkap. American Journal of Environmental Protection, 2, 41-50. https://doi.org/10. 12691/env-2-2-3

Tajuddin, T., Supratman, S., Salman, D., \& Yusran, Y. (2019). Bridging social forestry and forest management units: Juxtaposing policy imaginaries with implementation practices in a case from Sulawesi. Forest and Society, 3 , 97-113. https://doi.org/10.24259/fs.v3i1.6049

Uphoff, N. (2000). Understanding social capital: Learning from the analysis and experience of participation. Social Capital: A Multifaceted Perspective, 215-249.

Wulandari, C., \& Setyaso, A. (2014). Membangun profesionalisme SDM KPH. In Sugiharto, Strategi pengembangan KPH dan perubahan struktur kehutanan di Indonesia. Jakarta: Direktorat Jenderal Planologi Kehutanan Kementerian Lingkungan Hidup dan Kehutanan.

Wulandari, C., Budiono, P., \& Ekayani, M. (2019). Impacts of the new Decentralization Law 23/2014 to the implementation of community based forest management in Lampung Province, Indonesia. IOP Conference Series: Earth and Environmental Science, 285, 012006. https://doi.org/10.1088/1755-1315/285/1/012006

Yovi, E. Y., \& Nurrochmat, D. R. (2018). An occupational ergonomics in the Indonesian state mandatory sustainable forest management instrument: A review. Forest Policy and Economics, 91, 27-35. https://doi.org/ 10.1016/j.forpol.2017.11.007 